\title{
Seasonal Anomalies between S\&P CNX Nifty Shariah Index and S\&P CNX Nifty Index in India
}

\author{
${ }^{1}$ M. Dharani*, P. Natarajan ${ }^{1}$ \\ ${ }^{1}$ Department of Commerce, Pondicherry University, Puducherry, India \\ *mdharani85@gmail.com
}

\begin{abstract}
The present study compares the risk and return of the Nifty Shariah index and Nifty index at days, months and quarters wise during the period $2^{\text {nd }}$ January 2007 to $31^{\text {st }}$ December 2010. The raw returns of the both indices are calculated as today price minus yesterday price divided by yesterday price. The t- test has been used to test the mean returns difference between both indices. The average Monday return of the Nifty Shariah index is compared with average return of the Nifty index by using two sample t-test. Like that, the average returns of the remaining of the days of Nifty Shariah index are compared with average returns of remaining days of the Nifty Index. The study finds that there is no difference between average day -wise returns of the Nifty Shariah index and average day return of the Nifty Index during the study period. The study also compares the average January return of the Nifty Shariah index with average January return of the Nifty index, average February return of the Nifty Shariah index with average return of the Nifty index and so on. Finally, the average return of the first, second, third and fourth quarter of Nifty Shariah with average return of the respective first, second, third and fourth quarter of Nifty index are compared. The study finds that there is a significant difference between average return of the Nifty Shariah and Nifty indices in the month of July and September. It is derived from the study that the Muslim Investors are evincing more interest to sell the shares in the market from July to September. The reason being, expenses inconnection with Ramalan Festival during that period. Therefore, the study confirms that Ramalan effect have been prevailing in the Indian Stock Market. Thus, this study reveals that the seasonal variation exits very much in Shariah Index
\end{abstract}

Key words: Nifty Shariah, Islamic Index, Ramalan Effect, Seasonal effects, Day of the week effect

\section{Introduction}

Islamic Index or Shariah Index comprises Shariah Compliant stocks. Which means those stocks are included in index that successfully pass the Shariah Screening Norms on Industry and financial ratio filters. Due to its inherent advantages of being socially responsible, ethically sound and consistent performance, Shariah indices have of late become very popular with Investors globally. With more than 900 Shariah Compliant companies commanding 70\% of the total listed market capitalization Shariah Compliant Indian Markets offer a good opportunity for Islamic Equity Indices (Islamic Tijara, December 2010, p: 19). Studies based on Islamic indices are comparing Islamic indices with common indices for particular study period. Contrary to earlier studies, this study compares the seasonal Anomalies of the Islamic index with seasonal anomalies of the Common index in India.

One of the implications of the efficient market hypothesis (EMH) is that the expected returns on assets should be evenly distributed across the days, weeks, months, years or any other unit of time. But the empirical studies on the behaviors of stock returns have disclosed certain anomalies where variances in asset returns are found to be associated with the unit of time (Bandhani, 2004). Earlier studies have found the existence of the day of the week effect not only in the USA and other developed markets but also in the emerging markets like Malaysia, Hong Kong, Turkey). For most of the western economies, (U.S.A., U.K., Canada) empirical results have shown that on Mondays the market has statistically significant negative returns while on Fridays statistically significant positive returns. In other markets such as Japan, Australia, Singapore, Turkey and France the highest negative returns appear on Tuesdays. The day of the week effect in Indian market was examined by many researchers (Chaudhury, 1991, Poshakwala, 1996, Goswami and Anshuman, 2000, Choudhry, 2000, Bhattacharya, Sarkar and Mukhopadhyay, 2003). They analyses the seasonality pattern in common indices. But research regarding seasonal pattern on Islamic index or Shariah index is limited. Hence, the objective of the paper is to examine days of the week effect in the returns of S\&P CNX Nifty Shariah in Indian context. This study is also examined weekend effect and month of the year effect in S\&P CNX Nifty Shariah returns. 


\section{Review of Literature}

The Islamic Investments is in budding stage and gradually growing around the world for a decade. At the same time, the existing literature in the field of Islamic finance and Investments is limited. However, the available literature is presented to study the performance of Islamic index. Ahmad and Ibrahim (2002) compare the risk and return performance of Kuala Lumpur Shariah Index (KLSI) with Kuala Lumpur Composite index (KLCI) during the period 1999 to 2002. The sample period of the study is divided into growing period, decline period and overall period. They have employed relative return technique, Standard deviation, risk adjusted performance measurement and two sample $t$ - test to measure the performance of both indices. The study found that KLSI underperforms during overall period and decline period but it overperform in growing period. Finally they find that there is no significant difference in performance of both indices during thee sample period.

Hakim and Rashidian (2004) investigated the risk and return of Dow Jone Islamic Stock Market Indices (DJIM) from 1999 to 2002. The study found that the three month $\mathrm{T}$ bill returns dominate both the Islamic Index and the Wilshire 5000 stock market index. However, return and risk of the Islamic index is less than the Wilshire 5000. The study also examined the long run and short run relationship existing among the variables using unit root test, co integration and causality test. The study found that $\mathrm{T}$ bill returns, Islamic index returns and Wilshire 5000 returns are not co- integrated. Hussein (2004) evaluated the performance of ethical investment with their unscreened benchmarks. The study empirically tests whether returns of FTSE Global Islamic Index are significantly different from their index counterpart (FTSE All- World Index). The sample period is divided into two sub-periods, bull period (July 1996 March 2000) and bear period (April 2000 - August 2003). Both indices performed similar manner during entire sample period. On the other hand, the Islamic index yields statistically significant positive abnormal returns in the bull market period, whereas it underperforms in the bear market period. In general, the results show that the application of ethical screening does not have an adverse effect on the FTSE Global Islamic Index performance.

Hussein (2005) made an effort to test whether monthly returns of Financial Time Stock Exchange (FTSE) Global Islamic index and Dow Jone Islamic Market Index are significantly different from their common index for the period January 1996 to December 2004. The sample period is divided into bull market and bear market. The study employs Capital Asset pricing model, Risk adjusted performance measurement, $\mathrm{t}-$ test, Wilcoxon Signed test, buy and hold return method and cumulative return method for examining long run and short run relationship between indices. In short run period, Islamic indices statistically overperfom during whole period and second bull market period. In long run, Islamic indices overperfom during entire period and second bull market period. Finally, the study finds that there is a similar performance between indices. Rahman and Wajdi (2006) tried to examine whether Shariah-compliant firms pay higher dividend than non-Shariah-compliant firms during end of 2004. Further, they also attempted to provide empirical evidence on whether Shariah and non-Shariah compliant firms have different level of agency cost. The study uses Cost of sales, Sales and general administration expense, Annual sales, and Dividend per share as study variables. The result of the study shows that Shariahcompliant firms pay higher dividend to their shareholders than non-Shariah compliant firms. Further, this study found that Shariah-compliant firms facing less agency cost than non-Shariah compliant firm.

Yusof and Majid (2007) attempted to explore the extent to which the conditional volatilities of both conventional and Islamic stock markets in Malaysia are related to the conditional volatility of monetary policy variables. The narrow money supply (M1), the broad money supply (M2), interest rates (TBR), exchange rate (MYR), and Industrial Production Index (IPI) are used as monetary variables in this study, whereas the Kuala Lumpur Composite Index (KLCI) and Rashid Hussain Berhad Islamic Index (RHBII) are used as measures for conventional and Islamic stock markets, respectively. In order to capture the international influence on both stock markets, the volatility in the U.S. monetary policy variable measured by the Federal Funds Rate (FFR) is incorporated into the study. Generalized Autoregressive Conditional Heteroskedasticity (GARCH)-M, GARCH $(1,1)$ framework together with Vector Autoregressive (VAR) analysis are employed for the monthly data starting from January 1992 to December 2000 in this study. The study found that interest rate volatility affects the conventional stock market volatility but not the Islamic stock market volatility. This highlights the tenet of Islamic principles that the interest rate is not a significant variable in explaining stock market volatility. The results provided further support that stabilizing interest rate would have insignificant impact on the volatility of the Islamic stock markets. 
Albaity and Ahmad (2008) investigated the performance and relationship between KLSI and KLCE over the period of April 1999 to December 2005 in Malaysia. The study applied risk adjusted performance measurement, causality and Johansen co integration test. They found that there is an insignificant return difference and long run bidirectional relationship between both indices. Sadeghi (2008) investigated the impact of the introduction of Bursa Malaysia Islamic index on the financial performance and liquidity of the screening securities involved in the Islamic index in Malaysia. The study employed event study methodology to estimate mean cumulative returns of the Shariah compliant stocks in the days surrounding the event and also investigate the changes in liquidity using trade volume and bid ask spread surrounding the event days as liquidity proxies. The study found that the introduction of the Shariah index has positive and strong impact on the financial performance of the Shariah compliant stocks.

Mohd Dali et al (2008) endeavored to identify the performing and non-performing companies by using multiple discriminant analysis (MDA) and multiple regression and the ratios that could distinguish between the performing and the under-performing companies. First, the study applied the Jensen technique to classify the Shariah compliance companies into performing and non-performing companies. Then, the results from the Jensen technique with 20 financial ratios are applied to MDA in order to establish models that are used to identify non-performing and performing companies. The results have shown that the growth turnover ratio is the only ratio that could discriminate between the performing and non-performing companies in the plantation industry.

Beik and Wardhana (2009) discovered the relationship between Jakarta Islamic Index and other selected markets indices during the period of January 2006 to December 2008. The study apply Unit root test, Co integration and Vector auto regressive model (VAR) to examine the long run relationship among the selected sample indices in the study. The results confirmed that there is no long run relationship between Jakarta Islamic Index and other selected Market index during the study period. Seng et al (2009) empirically studied the performance of Shariha-Compliant Indices (SCIs) by evaluating the performance of number of SCIs, in comparison to similar mainstream indices, as well as in comparison to other ethical funds. Furthermore, the paper tested the co-integration among the SCI's and the mainstream ones to establish whether there is any scope for diversification. The main findings are that SCIs offer an opportunity for portfolio diversification with mainstream indices and other ethical funds within the UK.

Thus, the review of literature clearly states that Islamic investment has been flourishing in all over the world since 1970. But no such comprehensive study has been undertaken in India. Based on the earlier research studies, this study attempts to investigate seasonal effects in the performance of Shariah index in India. Globally, the existing research literature pertaining to Islamic indices is limited. However, Ahmad and Ibrahim (2002), Hakim and Rashidian (2002), Hussein (2005), and Albaity and Ahmad (2008) analyzed the performance of Islamic indices vis-à-vis conventional stock market indices. Most of the studies are carried out in the developed counties like USA, UK. Similar study in the field of Islamic investment in developing country like India is seldom made. Further, earlier studies are compared the performance of both indices for entire sample and sub sample period. The present study analyses the performance of the both indices at different time intervals such as days, moths and quarters in Indian context.

\section{Data and Methodology}

The data set of this study is closing price of the S\&P CNX Nifty Shariah (Islamic index in India) and S\&P CNX Nifty Index. The closing values of the both indices are collected from the National Stock Exchange (NSE) of India (www.nseindia.com) during the period 2nd January 2007 to $31^{\text {st }}$ December 2011. The closing price of the both indices is separated into day, month and quarter wise for the analysis purpose. First, this study calculates the return of the both indices by using the following formula.

$R_{\mathrm{i}}=\left(\mathrm{P}_{\mathrm{t}}-\mathrm{P}_{\mathrm{t}-1}\right) / \mathrm{P}_{\mathrm{t}-1}$

$R_{t}$ is a return of the index on day $t, P_{t}$ is a price of the index on day $t$ and $P_{t-1}$ is price of the index on day $t-$ 1. The above formula is used for calculating days, months and quarters wise return of the Islamic index and common index. Than, two sample $t$-test is applied to find out whether any significant different between both indices for days, months and quarters wise.

\section{Empirical Results}

\section{Day-wise Returns Analysis}

In this section, the study calculates the returns for days wise such as Monday, Tuesday, Wednesday, Thursday and Friday, by using daily price for both Nifty Shariah and Nifty during the sample study period. 
The results of the both indices for day's wise returns are presented in the table 1 and 2 . The study tests the following hypothesis.

$1 \mathrm{H}_{0}=$ Monday, Tuesday, Wednesday, Thursday and Friday returns of the Nifty Shariah index and Nifty index are normally distributed.

$2 \mathrm{H}_{0}=$ There is no difference between day-wise returns of the Nifty Shariah index and Nifty index

The table 1 discloses that mean return of the Nifty Shariah on Wednesday is lower than other days during the sample period. The return of the Nifty Shariah is increasing slightly upto Tuesday and comedown on Wednesday. Again it is increased upto Friday. At the same time, Standard deviation of the return on Wednesday is low. This indicates that volatility of the Nifty Shariah is low on Wednesday comparing with other days. The volatility also is increasing slowing from Monday to Tuesday and comedown on Wednesday. Again it is moving slowly from Thursday to Friday. The distributions of the return for all days are negatively skewed except Monday. The kurtosis value of the Nifty Shariah returns are greater than 3 for all days except Wednesday. The returns are not normally distributed for all days except Wednesday. That is Wednesday returns are normally distributed. The study concludes that the buying activities of the ethical investors in India are low on Wednesday.

Table 1: Day-wise returns of the Nifty Shariah during the sample study period.

\begin{tabular}{lccccc}
\hline Parameters & Monday & Tuesday & Wednesday & Thursday & Friday \\
\hline Mean & 0.271130 & 0.278675 & 0.229967 & 0.255561 & 0.271702 \\
Median & 0.559274 & 0.729382 & 0.463152 & 0.526722 & 0.879624 \\
Maximum & 22.42041 & 15.40625 & 14.73015 & 13.32342 & 15.43856 \\
Minimum & -16.23874 & -17.69237 & -12.67114 & -23.38252 & -15.94971 \\
Std. Dev. & 5.500977 & 5.326363 & 4.612424 & 4.740252 & 4.759023 \\
Skewness & 0.327751 & -0.216489 & -0.084581 & -1.165388 & -0.184095 \\
Kurtosis & 5.742987 & 4.093246 & 3.470154 & 7.092965 & 3.965071 \\
Jarque-Bera & $48.38478^{*}$ & $8.353545^{* *}$ & 1.581183 & $134.0336^{*}$ & $6.312635^{* *}$ \\
Probability & 0.000000 & 0.015348 & 0.453576 & 0.000000 & 0.042582 \\
Observations & 146 & 145 & 152 & 145 & 142 \\
\hline
\end{tabular}

Sources: complied from indices values disclosure of NSE

Note: $*, * * * * *$ significant at $1 \%, 5 \%$ and $10 \%$ level respectively.

Table 2: Day-wise returns of the Nifty during the sample study period

\begin{tabular}{cccccc}
\hline Parameters & Monday & Tuesday & Wednesday & Thursday & Friday \\
\hline Mean & 0.314066 & 0.334473 & 0.282494 & 0.304128 & 0.226018 \\
Median & 0.632637 & 0.410438 & 0.476108 & 0.437394 & 0.641835 \\
Maximum & 21.62128 & 17.31412 & 17.46922 & 17.18265 & 13.93755 \\
Minimum & -19.16869 & -19.34313 & -12.33795 & -20.46563 & -15.46598 \\
Std. Dev. & 5.614490 & 5.588452 & 4.873163 & 4.872378 & 4.620819 \\
Skewness & 0.200548 & -0.120923 & 0.142452 & -0.692473 & -0.192913 \\
Kurtosis & 5.747953 & 4.525328 & 4.163584 & 5.792890 & 3.974411 \\
Jarque-Bera & $46.9154^{*}$ & $14.410^{*}$ & $9.0889^{* *}$ & $58.7147^{*}$ & $6.4985^{* *}$ \\
Probability & 0.000000 & 0.000743 & 0.010626 & 0.000000 & 0.038803 \\
Observations & 146 & 145 & 152 & 145 & 142 \\
\hline
\end{tabular}

Sources: complied from indices values disclosure of NSE

Note: $*, * *, * *$ significant at $1 \%, 5 \%$ and $10 \%$ level respectively.

According to the table 2, the return of the Nifty index on Friday is lower than other days. The standard deviation of the Nifty daily returns is decreasing from day by days. This indicates that volatility of the Nifty index is more on Monday compared with other days. Jarque Bera test shows that days returns are not normally distributed and it reject the null hypothesis. The distribution of the Nifty daily returns is positively skewed on Monday and Wednesday where as negatively skewed on remaining of the days. Kurtosis indicates that the distribution is leptokurtic. The next table discloses the correlation and t-test between returns of Nifty Shariah index and Nifty index. 
Table 3: Results of Correlation and Two sample mean't' test between the Returns S\&P CNX Nifty Shariah and S\&P CNX Nifty Returns

\begin{tabular}{lccccc}
\hline Parameters & Monday & Tuesday & Wednesday & Thursday & Friday \\
\hline Correlation & 0.987 & 0.988 & 0.9837 & 0.9867 & 0.9837 \\
t- statistics & -0.575 & -0.75964 & -0.7255 & -0.7371 & -0.6363 \\
\hline
\end{tabular}

Note: Complied from daily closing value of the Nifty Shariah and Nifty

The table 3 reveals the results of correlation and t-test between both indices. The both indices are highly correlated for all the days. According to the t-test, there is no significant different return of the Nifty Shariah and Nifty indices. Therefore, this study is supporting the null hypothesis.

\section{Month-wise Returns Analysis}

In this section, the researcher analysis the monthly returns of the Nifty Shariah and Nifty indices during the study period. The descriptive statistics of the returns for both indices are presented in the following table 4 and 5 . This study tests the following null hypothesis.

$1 \mathrm{H}_{0}=$ Month wise returns of the Nifty Shariah index and Nifty index are normally distributed.

$2 \mathrm{H}_{0}=$ There is no difference between Month-wise returns of the Nifty Shariah index and Nifty index

Table 4: Descriptive statistics of the S\&P CNX Nifty Shariah Index for each Month

\begin{tabular}{cccccccc}
\hline Month & Mean & SD & Skw & Kurt & Jar-B & P & Obs \\
\hline Jan & 0.744 & 11.93 & 4.27 & 34.89 & 3680 & 0.00 & 81 \\
Feb & 0.732 & 11.47 & 3.47 & 34.30 & 3341 & 0.00 & 78 \\
Mar & 0.759 & 9.62 & 2.33 & 32.09 & 2785 & 0.00 & 77 \\
April & 0.657 & 7.62 & 0.680 & 33.422 & 2936 & 0.00 & 76 \\
May & 0.263 & 4.87 & -0.949 & 22.08 & 1226 & 0.00 & 80 \\
Jun & 0.182 & 2.35 & 2.50 & 14.05 & 521 & 0.00 & 85 \\
July & 0.164 & 2.68 & -0.887 & 13.14 & 388 & 0.00 & 88 \\
Agut & 0.106 & 1.812 & 1.242 & 9.84 & 185 & 0.00 & 84 \\
Sept & 0.218 & 2.96 & 1.21 & 24.251 & 1524 & 0.00 & 80 \\
Oct & 0.438 & 9.538 & 4.37 & 39.21 & 4741 & 0.00 & 82 \\
Nov & 0.269 & 9.30 & 2.15 & 36.28 & 3754 & 0.00 & 80 \\
Dec & 0.517 & 10.61 & 2.28 & 41.39 & 5109 & 0.00 & 82 \\
\hline
\end{tabular}

Note: Complied from daily closing value of the Nifty Shariah

The month wise mean returns of the Nifty Shariah Index and Nifty Index are presented in the table 4 and 5 respectively. The average return of the both indices is high in the month of March and very low in August. Therefore, the study finds that the budget effects prevailing in the stock market during the period of March every year. The standard deviation of the indices is more on January and very less in the month of August. This indicates that the Nifty Shariah and Nifty is more volatile in the month of January and low in August. The Positive skewness indicated that the returns distribution has a right tail and negative skewness implies that the distribution has a left tail. According to the kurtosis and Jarque Bera test, the Month wise return distribution is not normally distributed during the study period.

Table 5: Descriptive statistics of the S\&P CNX Nifty Index for each Month

\begin{tabular}{cccccccc}
\hline Month & Mean & SD & Skw & Kurt & Jar-B & P & Obs \\
\hline Jan & 0.806 & 11.89 & 4.356 & 33.234 & 3341 & 0.00 & 81 \\
Feb & 0.794 & 11.46 & 3.531 & 32.238 & 2940 & 0.00 & 78 \\
Mar & 0.863 & 9.86 & 2.93 & 31.87 & 2786 & 0.00 & 77 \\
April & 0.804 & 7.97 & 1.79 & 33.60 & 3006 & 0.00 & 76 \\
May & 0.368 & 4.81 & 0.52 & 18.21 & 774 & 0.00 & 80 \\
Jun & 0.287 & 2.84 & 3.05 & 16.15 & 745 & 0.00 & 85 \\
July & 0.288 & 2.83 & -0.428 & 13.49 & 406 & 0.00 & 88 \\
Agut & 0.288 & 2.499 & 3.48 & 23.31 & 1612 & 0.00 & 84 \\
Sept & 0.418 & 3.04 & 1.376 & 20.27 & 1019 & 0.00 & 80 \\
Oct & 0.624 & 10.23 & 4.83 & 39.58 & 4891 & 0.00 & 82 \\
Nov & 0.445 & 9.638 & 2.53 & 34.80 & 3456 & 0.00 & 80 \\
Dec & 0.624 & 10.48 & 2.14 & 39.48 & 4610 & 0.00 & 82 \\
\hline
\end{tabular}

Note: Complied from daily closing value of the Nifty Index 
Table 6: Results of Correlation and Two sample mean't' test between the Returns S\&P CNX Nift Shariah and S\&P CNX Nifty Returns

\begin{tabular}{|c|c|c|c|c|c|c|c|c|c|c|c|c|}
\hline Test & Jan & Feb & Mar & Apr & May & Jun & Jul & Aug & Sep & Oct & Nov & Dec \\
\hline Correlation & 0.99 & 0.99 & 0.99 & 0.99 & 0.98 & 0.91 & 0.98 & 0.93 & 0.96 & 0.99 & 0.99 & 0.99 \\
\hline t-stat & -0.75 & -0.73 & -1.19 & -1.66 & -1.26 & -0.84 & -2.31 & -1.64 & -2.24 & -1.31 & -1.62 & -0.90 \\
\hline
\end{tabular}

Sources: compiled from indices values disclosure of NSE

According to the table 6, the correlation between Nifty Shariah and Nifty Indices is strong. The t-tests suggest that there is return different between Nifty Shariah and Nifty during the month of July and September. The study rejects the null hypothesis that there is no different between both indices for July and September and accepts the null hypothesis for remaining the months. From this result, the study finds the Muslim Investors are selling shares in the market from July to September. The reason is that the Muslim Holy Festival i.e. Ramalan have celebrated in the month of July to October for last four years. Therefore, the study confirms that Ramalan effect have been prevailing in the Indian Stock Market.

\section{Quarter-wise Returns Analysis}

The study further analysis the quarter returns for Nifty Shariah and Nifty indices during the study period. The following null hypotheses are tested in this part of the study.

$1 \mathrm{H}_{0}=$ Quarter wise returns of the Nifty Shariah index and Nifty index are normally distributed.

$2 \mathrm{H}_{0}=$ There is no difference between Quarter-wise returns of the Nifty Shariah index and Nifty index

Table 7: Descriptive statistics of the S\&P CNX Nifty Shariah Index and Nifty Index for each quarter

\begin{tabular}{lcccccccc}
\hline \multicolumn{1}{c}{ Quarter/ } & \multicolumn{2}{c}{ I } & \multicolumn{3}{c}{ II } & \multicolumn{2}{c}{ III } & \multicolumn{2}{c}{ IV } \\
Parameters & Shariah & Nifty & Shariah & Nifty & Shariah & Nifty & Shariah & Nifty \\
\hline Mean & 0.267 & 0.305 & 0.165 & 0.199 & 0.099 & 0.160 & 0.176 & 0.216 \\
Median & 0.091 & 0.074 & 0.145 & 0.161 & 0.045 & 0.163 & -0.0108 & -0.032 \\
Maximum & 71.75 & 73.19 & 19.33 & 23.29 & 10.12 & 10.70 & 75.92 & 71.78 \\
Minimum & -39.74 & -35.93 & -29.17 & -24.26 & -20.56 & -22.39 & -36.22 & -35.64 \\
Std. Dev. & 6.66 & 6.92 & 2.96 & 2.94 & 2.16 & 2.31 & 5.86 & 5.73 \\
Skewness & 6.37 & 7.12 & -1.93 & 0.627 & -3.11 & -3.35 & 7.82 & 7.04 \\
Kurtosis & 78.31 & 79.92 & 52.76 & 41.53 & 36.54 & 38.84 & 120.37 & 106.4 \\
Jarque-Bera & 57855 & 60699 & 25221 & 15051 & 12315 & 14068 & 143710 & 11181 \\
Probability & 0.00 & 0.00 & 0.00 & 0.00 & 0.00 & 0.00 & 0.00 & 0.00 \\
Obs & 238 & 238 & 243 & 243 & 254 & 254 & 246 & 246 \\
\hline Sources:
\end{tabular}

Sources: complied from indices values disclosure of NSE

The mean quarter returns of the both indices during the study period are presented in the table 7 . According to the results, the returns of the both indices are higher in first quarter than other quarter. At the same time, standard deviation of the both indices in first quarter is high. This indicates that both indices are more volatile in first quarter than other quarter during the study period. The kurtosis and Jarque Bera test indicate that the return distribution of the both indices is not normally distributed. Therefore, the researcher rejects the null hypothesis that returns are normally distributed. Further, return distribution is leptokurtic.

Table 8: Results of Correlation and Two sample mean't' test between the Returns S\&P CNX Nifty Shariah and S\&P CNX Nifty Returns

\begin{tabular}{lllll}
\hline Test & I & II & III & IV \\
\hline Correlation & 0.996 & 0.982 & 0.988 & 0.992 \\
t-test & -0.784 & -0.945 & -2.649 & -0.826 \\
\hline
\end{tabular}

Sources: complied from indices values disclosure of NSE

Table 8 reveals that the both indices are highly correlated. Further, there is no difference between quarter mean return of the Nifty Shariah index and Nifty index during I, II and IV quarter and also it supporting the null hypothesis. During the III quarter, calculated t value is greater than table $t$ value. Hence, the study rejects the null hypothesis that there is no third quarter mean difference between Nifty Shariah and Nifty 
indices. Therefore, the study confirms that the Ramalan Effect is affecting the stock market movement in the Shariah Index in the Indian stock Market.

\section{Summary and Conclusion}

The present study compares the risk and return of the Nifty Shariah index and Nifty index at days, Months and quarters wise during the period $2^{\text {nd }}$ January 2007 to $31^{\text {st }}$ December 2010 . The raw returns of the both indices are calculated as today price minus yesterday price divided by yesterday price. The $t$ - test is used to test the mean returns difference between both indices. The average Monday return of the Nifty Shariah index is compared with average return of the Nifty index by using two sample t-test. Like that, the average returns of the remaining of the days of Nifty Shariah index are compared with average returns of remaining days of the Nifty Index. The study finds that there is no difference between average day wise returns of the Nifty Shariah index and average day return of the Nifty Index during the study period.

The study also compares the average January return of the Nifty Shariah index with average January return of the Nifty index, average February return of the Nifty Shariah index with average return of the Nifty index and so on. Finally, the average return of the first, second, third and fourth quarter of Nifty Shariah with average return of the respective first, second, third and fourth quarter of Nifty index are compared. It reveals that there is a significant difference between average return of the Nifty Shariah and Nifty indices in the month of July and September. It is derived from the study that the Muslim Investors are evincing more interest to sell the shares in the market from July to September. The reason being, expenses inconnection with Ramalan Festival during that period. Therefore, the study confirms that Ramalan effect have been prevailing in the Indian Stock Market. Thus, this study reveals that the seasonal variation exits very much in Shariah Index

\section{References}

Ahmad, Z. and Ibrahim, H. (2002). A Study of Performance of the KLSE Syariah Index, Malaysian Management Journal, 6 (1\&2): 25-34.

Albaity, M. and Ahmad, R. (2008). Performance of Syariah and Composite Indices: Evidence from Bursa Malaysia. Asian Academy of Management Journal of Accounting and Finance. 4(1): 23-43.

Beik, S. I. and Wardhana, W. (2009). The Relationship between Jakarta Islamic Index and Other Selected Markets: Evidence from Impulse Response Function. Persatuan Pelajar Indonesia International Islamic University Malaysia. ppi-iium.org/.../ The\%20Relationship\%20 between\%20JII\%20\&\%20US.pdf.

Bhattacharya, K., Sarkar, N. and Mukhopadhyay, D. (2003). Stability of the day of the week effect in return and in volatility at the Indian capital market: a GARCH approach with proper mean specification, Applied Financial Economics. 13: 553- 563.

Bandhani, K. N. (2004). Anomaly or Rationality: Explaining the Day-Of-The-Week Effect on S\&P CNX Nifty Index-Returns during Different Settlement Regimes. Kumaun University Working paper, 2007.

Chaudhury, S. K. (1991). Seasonality in share returns: preliminary evidence on day of the week effect. Chartered Accountant (India). 40: 107-9.

Choudhury, T. (2000). Day of the week effect in emerging Asian stock markets- Evidence from GARCH model, Applied Financial Economics. 20: 235-42

Goswami, R. and Anshuman, R. (2000). Day of the week effect on Bombay Stock Exchange. ICFAI Journal of Applied Finance. 6: 31-46.

Hakim, S. \& Rashidian, M. (2004). How costly is investor's compliance to Sharia? Paper presented at the 11th Economic Research Forum Annual Conference in Sharjah, U.A.E. on December 14-16

Hakim. S. \& Rashidian, M. (2002). Risk and Return of the Islamic Stock Market, Paper presented at the presentation to Economic Research Forum Annual Meetings, Sharjah, UAE.

Hussein, A. K. (2004). Ethical Investment: Empirical Evidence From FTSE Islamic Index. Islamic Economic Studies, 12(1): 21-40.

Hussein, A. K. (2005). Islamic Investment: Evidence From Dow Jones and FTSE Indices, Working paper, Islamic Business Research Centre, Norway.

Mohd Dali, N. R. S. B., Mudasir, H. H. and Hamid, S. A. (2008). Performance of Shariah compliance companies in the plantation industry. International Journal of Islamic and Middle Eastern Finance and Management. 1(2):166-178.

Poshakwale, S. (1996). Evidence on weak form of efficiency and day of the week effect in the Indian stock market. Finance India. 10: 605-16. 
Rahman, F. A. and Wajdi, F. M. (2006). Dividend Signaling Hypothesis and Agency Cost: An Investigation on Shariah and Non Shariah Compliant Firms in Kuala Lumpur. Shariah Index Empirika, 19(1):19.

Sadeghi, M. (2008). Financial Performance of Shariah-Compliant Investment: Evidence from Malaysian Stock Market. International Research Journal of Finance and Economics, 20: 15-26.

Seng, K., Gianluigi. G. and Jason, L. ( 2009). Performance of Shariah-Compliant Indices in London and NY Stock Markets and their potential for diversification. International Journal of Monetary Economics and Finance, 2(3/4): 398-408.

Yusof, M. R. and Abd. Majid, S. M. (2007). Stock Market Volatility Transmission in Malaysia: Islamic Versus Conventional Stock Market J. KAU: Islamic Econ. 20(2): 17-35. 